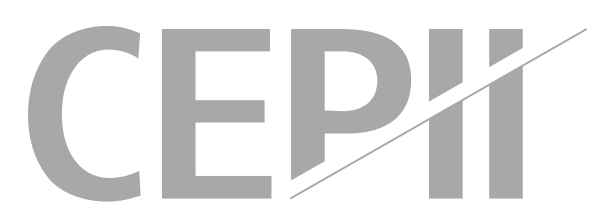

\title{
TBTs, Firm Organization and Labour Structure
}

Giorgio Barba Navaretti, Lionel Fontagné, Gianluca Orefice, Giovanni Pica \& Anna Cecilia Rosso

\section{Highlights}

- Exporters respond to increased complexity associated with restrictive Technical Barriers to Trade at destination by raising the share of managers at the expense of blue collars, white collars and professionals.

- The share of engineers in production increases when the firm faces a new technical standard at destination.

- New stringent technical standard at destination forces the firm to adapt workforce composition by hiring workers able to adapt the product to the new standard. 


\section{Abstract}

This paper investigates the effects on firms' occupational structure of shocks induced by the introduction of Technical Barriers to Trade (TBTs) in importing countries. We rely on the Specific Trade Concern (STC) data released by the WTO to identify trade-restrictive TBT measures, combined with matched employer-employee data for the population of French exporters over the period 1995-2010, and with information on the list of product-destinations served by each French exporter. Controlling for time-invariant firm/occupation effects and for time-varying sector/occupation shocks, IV estimates show that exporters respond to increased complexity associated with restrictive TBTs at destination by raising the share of managers at the expense of blue collars, white collars and professionals. This evidence is consistent with the growing literature exploring how firms organize their workforce composition in presence of exogenous (foreign) shocks; and it is also related to the well-beaten literature on the labour market effects of trade.

\section{Keywords}

Skill Composition, Labor Demand, Job Polarization, Trade Barriers.

\section{JEL}

F13, F14, J53.

\section{Working Paper}

CEPII (Centre d'Etudes Prospectives et $d^{\prime}$ 'Informations Internationales) is a French institute dedicated to producing independent, policyoriented economic research helpful to understand the international economic environment and challenges in the areas of trade policy, competitiveness, macroeconomics, international finance and growth.

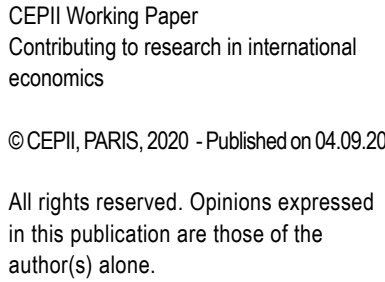

CEPII Working Paper Contributing to research in international economics

CCEPII, PARIS, 2020 - Published on 04.09.20

All rights reserved. Opinions expressed in this publication are those of the author(s) alone.

$\begin{array}{ll}\text { Editorial Director: } & \text { CEPII } \\ \text { Sébastien Jean } & \text { 20, avenue de Ségur } \\ & \text { TSA 10726 } \\ \text { Production: } & 75334 \text { Paris Cedex } 07 \\ \text { Laure Boivin } & +33153685500 \\ & \text { www.cepii.fr } \\ \text { No ISSN: } 1293-2574 & \text { Press contact: presse@ }\end{array}$




\title{
TBTs, Firm Organization and Labour Structure ${ }^{1}$
}

\author{
Giorgio Barba Navaretti (Università degli Studi di Milano and LdA)* \\ Lionel Fontagné (Paris School of Economics - Université Paris I, CEPII and CESifo) ${ }^{\dagger}$ \\ Gianluca Orefice (Université Paris-Dauphine, PSL) $)^{\ddagger}$ \\ Giovanni Pica (Università della Svizzera Italiana, LdA and CSEF)§ \\ Anna Rosso (Università degli Studi di Milano, LdA and CEP)
}

\section{Introduction}

Trade shocks in export markets may affect the relative demand for skills (Burstein and Vogel, 2017; Harrigan and Reshef, 2015; Yeaple, 2005; Biscourp and Kramarz, 2007). Trade policies that impose new technological standards in destination markets may also affect the occupational structure of exporting firms, as they require to devise and implement new production and/or organizational processes. More specifically, new technological standards raise skill-intensive fixed export costs, due to the need to adapt the production process, as well as to additional coordination requirements and marketing needs, and therefore they alter the relative demand for skills. ${ }^{2}$ This paper investigates the effects on firms' occupational structure of shocks induced by the introduction of a specific class of Non-Tariff Measures NTMs in exporting countries, namely stringent Technical Barriers to Trade (TBTs).

Analyzing the employment effects of NTMs is extremely relevant in the light of their increasing importance. Trade policy has recently undergone profound transformations. Multilateral agreements, Preferential Trade Agreements and unilateral episodes of trade liberalization have limited the use of tariff measures as an instrument of trade policy. Therefore, policymakers increasingly

\footnotetext{
${ }^{1}$ We thank Sante De Pinto for excellent research assistance. We are also indebted to the participants of the 2017 Paris Pronto Workshop, and in particular to our discussant Ron Davis. This paper was produced as part of the project "Productivity, Non-Tariff Measures and Openness" (PRONTO) funded by the European Commission under the 7th Framework Programme, Theme SSH.2013.4.3-3 "Untapped Potential for Growth and Employment Reducing the Cost of Non-Tariff Measures in Goods, Services and Investment", Grant agreement No. 613504.

*barba@unimi.it

$\dagger$ lionel.fontagne@univ-paris1.fr

$\ddagger$ gianluca.orefice@dauphine.psl.eu

$\S$ giovanni.pica@usi.ch

Ianna.rosso@unimi.it

${ }^{2}$ Matsuyama (2007) argues that fixed export costs are skill intensive because they involve services and tasks related to marketing, research, communication and logistic knowledge. Brambilla et al. (2012) provide empirical evidence in support of this view.
} 
resort to NTMs to obstacle trade and protect domestic producers. ${ }^{3}$ NTMs imply non-negligible increases in trade cost, and often represent an impediment to trade (see World Trade Report 2012; Fontagné et al. 2015; Crivelli and Groeschl 2016; Fontagné and Orefice 2018; Grundke and Moser 2019).

Within NTMs, we focus on the most stringent TBTs identified here as those challenged by exporters in the dedicated WTO committee. TBTs are measures that impose technical requirements on exporting firms as they refer to technical regulations (and the related assessment of conformity) and specific characteristics of a product; such as quality, production process methods, labeling and packaging characteristics. ${ }^{4}$ While these measures are not explicitly aimed at restricting trade, and are often actually intended to protect the environment, consumer safety and national security, in many instances they do act as effective trade barriers (see WTO (2012) for a survey) and even respond to reductions in import tariffs (Orefice, 2017; Francois et al., 2011; Beverelli et al., 2019).

Of course, not all TBTs are trade-restrictive, as they disseminate information on products' characteristics and reduce uncertainty to the benefit of the consumer. However, a subset of TBTs are restrictive enough (i.e. imply considerable increases in export cost), and potentially unjustified on safety or other acceptable grounds, such that exporting countries challenge them and are object of Specific Trade Concerns (STCs) in the dedicated committee at the WTO. ${ }^{5}$ Trade restrictive TBT measures represent a particularly suitable example of increases in fixed export costs. ${ }^{6}$ In this paper we explicitly look at how STCs on TBT (reflecting actual increases in fixed export costs) affect the occupational composition of firms. ${ }^{7}$

\footnotetext{
${ }^{3}$ Pascal Lamy, the former Director General of the World Trade Organization (WTO), in his farewell statement in July 242013 evoked the increasing role of NTMs as potential protectionist policies: "The issue today is with the difficulties involved in trade opening. Domestic trade politics have become more difficult and trade deals have become more complex because the nature of obstacles to trade has evolved. We are no longer negotiating just the reduction of tariffs, but also of non-tariff barriers, which have gained enormous importance".

${ }^{4}$ In particular, a technical regulation is "a document that sets out product characteristics or related processes and production methods, including the applicable administrative provisions, with which compliance is mandatory. It may also include or deal exclusively with terminology, symbols, packaging, marking or labeling requirements as they apply to a product, process or production method" (UNCTAD (2019)). The International classification of NTMs is available at: https://unctad.org/en/Pages/DITC/Trade-Analysis/Non-Tariff-Measures/ NTMs-Classification.aspx. A detailed definition of TBTs is provided at: https://unctad.org/en/Pages/ DITC/Trade-Analysis/Non-Tariff-Measures/MAST-Group-on-NTMs . aspx.

${ }^{5}$ Specific Trade Concerns (STCs) on TBTs are cases raised at the WTO TBT Committee by a complaining country (one or more) against a technical standard imposed by another WTO member state on a (claimed) unjustified basis.

${ }^{6}$ In earlier work, Fontagné and Orefice (2018) have shown that trade restrictive TBTs impact mainly the extensive margin of trade for French companies, with a small (weak) effect on the intensive margin. The same conclusion holds in sector-aggregated estimations. In the framework of trade models with heterogeneous firms (Chaney 2008), this outcome is consistent with an increase in fixed rather than variable export costs, and justifies interpreting the imposition of new TBTs as an increase in fixed export costs.

${ }^{7}$ While TBTs arguably raise fixed export cost, other NTMs, such as Sanitary and Phyto-Sanitary or the PreShipment Inspection measures represent a mix of fixed and variable export cost (see Fontagné et al. 2015 and 2020), and therefore are less likely to affect firms' skill intensity. TBTs differ from Sanitary and Phyto-Sanitary measures (SPS) as the former relate to technical standard of mainly manufacturing products, while the latter
} 
In the present paper, we exploit the variability of restrictive TBTs over time and their different occurrence in different markets for a given category of products as a trade shock for exporters. Our identification strategy relies on exogenous variation in the exposure of exporters to restrictive TBT measures (i.e. TBTs on which a concern has been raised) on their different markets. We observe the year of introduction of the concern at the WTO committee and the duration of the case at the HS4 product category and destination level. Detailed French data allow us to observe the product-destination composition of exporting firms, from which we can build firm-level time-varying measures of exposure to trade-restrictive TBTs.

To properly identify the effects of such trade obstacles, we need to isolate the impact of TBTs from the impact that other determinants of export behavior have on the occupational composition of the firm. So, other trade obstacles, such as transport costs or tariffs at destination, have to be considered and controlled for in the empirical exercise. ${ }^{8}$ Beyond trade, we also need to control for technological shocks potentially affecting the within-firm job composition. Our empirical approach relies on the assumption that such technological shifts are sector $\times$ occupation $\times$ timespecific and fully captured by a set of time-varying sector-occupation fixed effects. Finally, other unobserved firm-specific (time-invariant) characteristics, such as average productivity, management structure and the quality of managers are captured by firms $\times$ occupation-specific fixed effects.

Despite this rich set of controls, concerns may arise that the lobbying activity of firms determine which TBT to challenge in the WTO committee. This concern is strongly reduced in our study for two reasons. First, EU-raised STCs are unlikely to be affected by a specific French firm. Second, firm fixed effects fully control for the average (time-invariant) lobbying power of each firm. An additional concern originates from the fact that the number of TBTs faced by a firm may depend on the choice of the markets each firm decides to serve. Insofar as self-selection into high- or low-TBT intensive destinations depends on time-invariant factors, such as managerial ability, this is, again, captured by firm fixed effects. However, to further address any remaining reverse causality concerns and the possibility of endogenous selection of firms into destination markets induced by time-varying firm-specific shocks, we propose an Instrumental Variable approach in which the presence of a EU-raised TBT Specific Trade Concern is instrumented by the presence of a Non EU-raised STC. Such an instrument is unlikely to be correlated either with the lobbying power of French firms or with firm-level shocks triggering entry in destination markets.

We gather firm-specific information from several individual- and firm-level data sources from

concern mainly food and agri-food product and their ingredient composition (contents of pesticides, ingredient mix, etc). Therefore, from a purely economic perspective, while the imposition of a TBT implies almost exclusively a rise in the fixed export cost (see Fontagné and Orefice 2018), the imposition of an SPS implies an increase in both variable and fixed export costs (see Fontagné et al. 2015).

${ }^{8}$ Of course, the overall demand for labor may shift in reaction to changes in exports. Our analysis is not concerned with the impact of TBTs on the level of employment in exporting firms, but rather on the composition the workforce within the firm. 
France. We measure the composition of the workforce in French firms in terms of professional categories exploiting the DADS (Déclarations Annuelles des Données Sociales), a matched employer-employee large-scale administrative database. ${ }^{9}$ The professional categories include managers (further split in several subcategories), professionals, white collars, qualified blue collars and non qualified blue collars. ${ }^{10}$ We also exploit information on the list of productdestinations served by each French exporter over the period 1995-2010 (customs data provided by the Direction Dénérale Des Douanes et Droits Indirects, DGDDI). Finally, as mentioned above, we rely on restrictive TBTs as revealed by Specific Trade Concern, at HS 4-digit and by destination, so that for each firm we are able to compute the number of exported varieties (i.e. product-destination combinations) under technical standards (TBT) that really imply an increase in the cost of exporting due to additional complexity of the firm's process.

Controlling for firm $\times$ occupation-specific time-invariant unobserved heterogeneity, time-varying sector $\times$ occupation shocks, and tariffs at destination, we find that one additional Specific Trade Concern on TBT implies a 0.3 percentage point increase in the firm's share of managers (i.e. the top hierarchical layer). When instrumenting the EU-raised TBTs faced by French firms in a given destination-sector with the TBTs raised by non-EU countries in the same destinationsector to account for residual endogeneity concerns, we find that one additional TBT concern increases the share of managers by 1 percentage point. The average increase in the share of managers in the firm facing a restrictive TBT is matched with a decrease in the share of all other occupational groups (in particular qualified and non-qualified blue collar occupations). Among managers, it is shown that exporters affected by TBTs at destination resort to an increase in the share of salaried head of enterprise and engineers. These results illustrate how firms respond to the increased complexity caused by more stringent TBTs (i.e. adaptation cost) by raising the proportion of workers employed in managerial positions, the highest hierarchical layer. Our results are in line with previous literature highlighting the skilled workers intensity of fixed export costs (Matsuyama, 2007; Brambilla et al., 2012). We add to this stream of literature by characterizing the specific occupational groups (among skilled workers) that are used by firms to overcome the TBT-driven increases in fixed export costs.

This paper bridges together two strands of literature. The first is the one on the labor market consequences of trade. While the early empirical evidence suggested that such effects were small, increasing wage inequality being ascribed to skill-biased technological change, recent evidence has challenged this view. It is now established that, in the US manufacturing sector over the period 1991-2011, local labor markets highly exposed to import competition from China experienced larger job losses than less exposed areas (Acemoglu et al., 2016; Autor et al., 2013). More generally, the polarization of the labor market has been explained by the combination of trade and technological progress (both trade exposure and the share of hours worked in

\footnotetext{
"We use "DADS-postes": it covers the universe of firms. The drawback is that individual characteristics of employees such as education are not observable.

${ }^{10}$ See section 2.2 for detailed description of occupation groups.
} 
technology-related occupations grew hand in hand implying the difficulty to disentangle their respective responsibilities). Using data on 16 Western European countries, Goos et al. (2014) study the role of offshoring and technological change on the job polarization of EU labor markets over the period 1993-2010. In particular, they show the rise in employment shares for highpaid professionals, managers and low-paid personal service workers; and the contemporaneous fall in the employment share for manufacturing routine office workers. Using matched French employer-employee data from 1994 to 2007, Harrigan et al. (2020) find a polarization particularly detrimental to middle wage occupations. Using matched employer-employee Danish data over the period 1999-2009 Keller and Utar (2016) attribute one sixth of the decline in mid-skills workers employment to the Chinese import competition. Friedrich (2020) finds that an increase in firm's layers leads to an increase in inequality within the firm. He uses a trade shock that happened in Denmark in 2006, the Cartoon Crisis, to show that a decrease in exports of firms that traded with Muslim countries caused a decreased in layers for complying firms. ${ }^{11}$ However, due to the scant availability of data on firms' employment and workforce composition, no clearcut conclusion emerges from this literature on the firm's occupational composition effect of trade shocks. Also, little attention has been paid to the consequences of shocks faced on the export (rather than on the import) side. ${ }^{12}$ These two points represent the main contributions of our paper within the broad literature on trade and labour markets.

The second strand of literature we touch upon is the one that explores how firms organize production in hierarchies to economize on their use of knowledge (Garicano, 2000; Caliendo and Rossi-Hansberg, 2012) and predicts that firms react to shocks by managing the number of layers in the organization. ${ }^{13}$ We complement this literature by looking at whether firms respond

\footnotetext{
${ }^{11}$ Trade shocks may also affect the portfolio composition of exporting firms. This channel has also been analyzed in (Bernard et al., 2011; Mayer et al., 2014; Fontagné et al., 2018).

${ }^{12}$ Two exceptions are Bas and Bombarda (2013) and Maurin et al. (2002) who consider the labor market consequences of trade liberalization at destination (but they do not focus on the job composition of firms). Bas and Bombarda (2013) rely on firm level exports data to assess the impact of increased access to the Chinese market. As a result of the combination of market size and increased competition it is shown that lower Chinese import tariffs account for 18 percent of additional French export sales. Maurin et al. (2002) explore the export based channel of the demand for skills. Using French firm level data they show that becoming an exporter requires an investment in development and marketing, hence an upgrade of the skill composition of the firm. A more recent work that focuses on the US between 1991 and 2011 by Feenstra et al. (2019) shows that export expansion also created new jobs that, at the industry level, largely offset the job loss due to Chinese import competition, yet the net effects dissipates at the community zone level, confirming instead a net job loss.

${ }^{13}$ Using French data, Caliendo et al. (2015) find evidence that French manufacturing firms grow by actively managing the number of layers in their organization, while Rossi-Hansberg et al. (2020) find that expanding Portuguese firms add layers of (middle) managers. More broadly, the present paper adds also to the literature on the relationship between executive team structure, market competition and firm's product choice (Guadalupe et al., 2014; Bresnahan et al., 2002; Guadalupe and Wulf, 2010). In Guadalupe and Wulf (2010) authors find that market competition induced by trade liberalization pushes firms to increase the number of managers reporting directly to the CEO and to reduce the number of positions between the CEO and the division managers (hierarchy). Guadalupe et al. (2014), by using panel data on management positions in 300 US firms, show that firms that diversify their products (i.e. firm operating in more than 2-digit SIC segments) have a higher number of managers reporting directly to the CEO. In the same vein Bresnahan et al. (2002) show that firms introducing new products and services (i.e. innovative firms) demand more skilled workers. Sforza (2019) study how different shocks affect firm organization. He looks at how a credit supply shock differs from a trade shock. The latter is found to have a more
} 
to technical barriers by increasing managerial complexity through an expansion of the share of managers in total employment, hence through a reshaping of the organizational pyramid, with managers growing at the expense of less qualified positions. ${ }^{14}$

The paper proceeds as follows. Section 2 describes the data and presents basic descriptive statistics. Section 3 discusses the empirical strategy. Section 4 presents our baseline results. Section 5 concludes.

\section{Data description and sample selection}

In this section we present the data employed in our empirical exercise. STC and French Customs data are presented in section 2.1. In section 2.2 we discuss the matched employer-employee data and the workers' occupation classification adopted to define the employment shares by occupation category. In section 2.3 we present some descriptive statistics concerning the presence of TBT barriers.

\subsection{Specific Trade Concerns on TBT}

We use Specific Trade Concern (STC) data released by the WTO to identify trade restrictive Technical Barriers to Trade (TBT). ${ }^{15}$ All the WTO member states have the possibility of raising a concern at the TBT WTO Committee against a technical standard imposed by another member (STC). ${ }^{16}$ The TBT WTO Committee usually holds three formal meetings per year. Meetings are open to all WTO members, governmental observers and intergovernmental organization, and analyze each concern raised by member states (i.e. technical standard affecting complaining country's trade), and deliberate on whether the challenged technical standard is legitimately imposed or not. ${ }^{17}$ If not, the imposing country has to remove the technical standard. ${ }^{18}$ STC are therefore raised by complaining country only if the underlying standard has a non-negligible negative effect on trade. For this reason, by focusing on TBT STC we rely

negative effect on lower skill production workers with the effect being less pronounced as skills raise.

${ }^{14}$ This study also speaks to the literature finding that companies with more effective management are more likely to engage in exporting, and that management is disproportionately more important for trade operations than for domestic ones (Van Reenen et al., 2020).

${ }^{15}$ We discard trade concerns raised on Sanitary and Phytosanitary measures (SPSs) because they constitute a mix of fixed and variable costs with unclear expected consequences on the occupational structure of firms. Following Matsuyama (2007) we do expect only fixed export cost related shocks affect the skill composition of firms. SPSs are mostly related to the contents of food products (ingredient mix) and do not concern technological and/or technical standard to be complied with (small fixed costs component attached to SPS). Indeed, as showed in Fontagné et al. (2015) the imposition of a new SPS measure implies a mix of variable and fixed costs for the exporting firms.

${ }^{16}$ Notice that raising a STC is a prerogative of member states. Single firms are not allowed to raise autonomously STC at the WTO committee. The possibility that a single firm might lobby its government to raise a STC is discussed in section 3 and addressed by both the inclusion of firm fixed effects and our IV strategy.

${ }^{17}$ The discussion at the WTO Committee can be on existing (in force) or in the pipeline TBT measures.

${ }^{18}$ Information and official documents concerning each TBT STC are publicly available through the TBT Information Management System of the WTO. See http://tbtims.wto.org/ 
only on technical standards entailing a considerable trade costs (adaptation to the technical standard) for exporting firms.

When one or several WTO members raise a concern at the TBT WTO Committee over a non-tariff measure, they specify the country imposing the measure, the product of concern and the objective of the measure concerned. ${ }^{19}$ All this information is recorded and made available by WTO. ${ }^{20}$

A collection of all STCs provides a systematic set of all the TBT measures perceived as sizable trade barriers by exporters. Indeed, the measures have to be sufficiently important for exporting countries to raise a "concern" at the WTO. For this reason, we can be fairly sure that our data do identify barriers to trade. This is an important advantage with respect to using other TBTs sources based on exhaustive list of measures in place. Indeed other datasets (as TRAINS or Perinorm), by listing all the measures imposed by a country, mix together measures that restrict trade with those that might even increase trade. ${ }^{21}$

Overall, the TBT-STCs database contains information respectively on 318 specific trade concerns raised over the period 1995-2010. For each concern, we have information on: (i) the country raising the concern, (ii) the country imposing the measure, (iii) the product codes (HS 4-digit) involved in the concern, (iv) the year in which the concern has been raised to the WTO and (iv) whether it has been resolved and how. So we build a panel dataset tracking the presence of an ongoing STC on TBT for a specific country pair (imposing-complaining country) and product combination over time. ${ }^{22}$ Then we disentangle the STCs raised by EU (which are the relevant ones for French firms exports) from those raised by non-EU countries (used to build our instrumental variable in what follows). Finally, we collapse this dataset by HS 4-digit, destination and year, keeping the information on whether a given product-destination combination has at least one ongoing STC on TBT raised by EU and/or extra-EU member (in a given year). Importantly, concerns are raised, then discussed in the committee, and withdrawn after a while, generally based on a gentleman agreement amending the regulation. Some concerns failed to be fixed, and nevertheless the case may disappear if the exporting country considers that it cannot be solved and that its exporters will adjust and comply. Notice that a concern is considered solved by the WTO if it is not raised in the dedicated TBT committee for two years or more. Then, the date of the last raising at the TBT committee is assumed to be the date of the resolution of the STCs. ${ }^{23}$

\footnotetext{
${ }^{19}$ The TBT committee provide to WTO members a forum where discussing issues related to technical measures imposed by other members.

${ }^{20}$ The STC dataset is available at http://www.wto.org/english/res_e/publications_e/wtr12_dataset_e. htm.

${ }^{21}$ Technical standards might reveal consumer tastes at destination.

${ }^{22}$ This represents an additional advantage to the use of alternative dataset (e.g. by WITS) who provide only cross-sectional information on the presence of TBTs.

${ }^{23}$ The publicly available dataset does not include the year of resolution of STCs. On this respect we benefited from a confidential data by the WTO, in which a STCs on TBT is assumed to be solved if it is not raised in WTO
} 
The STC TBT dataset is then used to compute the number of stringent TBTs faced by each French exporter. To this end we matched STC data with French Custom data providing information on the list of product-destination served by a given French exporter over the period 1995-2010. ${ }^{24}$ For each firm we have information on the export value into a given productdestination. The dataset classifies product categories using Combined Nomenclature at 8 digits (CN8) but it has been aggregated here at HS 4-digit level to be consistent with the STCs dataset. Then we merge individual exports with STCs by HS 4-digit and destination, so that for each firm we computed the number of exported varieties (i.e. product-destination combinations) affected by a TBT-STC. Each firm has a unique identification code ("SIREN") that allows us to match custom/STC data with DADS data discussed in the next section.

\subsection{Matched employer-employee data}

We measure the composition of the workforce in French exporting firms exploiting the DADS (Déclarations Annuelles des Données Sociales), a matched employer-employee large-scale administrative database. These data are based upon mandatory employer reports of the earnings of each employee subject to French payroll taxes which essentially apply to all employed persons in the economy (including self-employed). Each observation in DADS corresponds to a unique individual-plant combination in a given year, with detailed information about the plantindividual relationship, including the number of days during the calendar year that individual worked in that plant, the (gross and net) wage, the type of occupation (classified according to socio-professional categories), the full time/part time status of the employee. Moreover, it provides the fiscal identifier of the firm that owns the plant, the geographical location of both the employing plant and firm, as well as the industry classification of the activity undertaken by the plant/firm. The data span the 1995-2010 period. Since we are interested in the job composition of firms, we have to disregard micro-firms. For this reason we restrict the analysis to companies having at least 5 employees after removing workers with missing and zero gross wages.

Before moving to the descriptive and econometric evidence, we need to clearly define the occupation groups considered in what follows. Based on the French occupation classification (Catégories Socioprofessionelles, CS 2-digit), we follow Caliendo et al. (2015) and categorize workers on the basis of their hierarchical level in the organization, which mimics (although imperfectly) the skill content of occupations within a firm. To this purpose, as shown in Table A1, we define five occupational categories: (i) managers (PCS codes from 21 to 38), (ii); professionals (PCS codes from 42 to 48), (iii) white collars (PCS codes from 53 to 56), (iv)

committee for two years or more. The date of the last raising at the TBT committee is assumed to be the date of the resolution of the STCS.

${ }^{24}$ Provided by the DGDDI (Direction Dénérale Des Douanes et Droits Indirects), these data are subject to statistical secrecy and are quasi exhaustive of the universe of French exporters. There is only a declaration threshold of 1000 euros that applies to any extra-EU destinations (for European countries such threshold is higher and around 150000 euros). 
qualified blue collars (PCS codes from 62 to 65$),(v)$ non-qualified blue collars (PCS codes from 67 to 69$) .25$

\subsection{Descriptive statistics}

This section aims at showing the relevance of restrictive TBTs for French firms, and a first descriptive evidence of the correlation between the imposition of TBTs at destination and the occupational composition of French firm.

Figure 1 shows two graphs: the left panel reports the evolution of the total number of destinationHS4 combinations with ongoing STCs on TBTs raised by the EU between 1995 and 2010, ${ }^{26}$ while the right panel shows the evolution of the share of exports towards destination-product combinations under active STCs on TBTs (share over the total value of French exports). To closely follow our econometric exercise, both measures are computed on the sample of HS4 sectors and firms used in the econometric estimations. The number of TBT concerns varies a lot over time, increasing to almost 400 concerns before the year 2000 , decreasing to almost zero between 2000 and 2001 and then peaking again in 2003 and in 2009. ${ }^{27}$ The peaks in 2003 and 2009 in the number of varieties under TBT STCs (left panel in figure 1) mirrors into the relatively high share of French exports under TBT STCs observed in years 2003 and 2009 (right panel of figure 1 ). The large variation over time (and across products) of STC TBT measures is key for our identification strategy based on the within variation of TBT-induced change in fixed export cost (see the next section).

Figure 2 provides a visual representation of what we aim at testing in our econometric exercise. It plots the change in the average number of TBTs faced by a French firm belonging to a given HS 4-digit sector over the period 1995-2010 (horizontal axis), ${ }^{28}$ against the change in the average share of employees by occupation group in each HS 4-digit manufacturing sector (vertical axis). The figure shows that, in HS 4-digit sectors with more intense increases in the number of stringent TBT measures, we observe larger changes in the share of managers (panel 1 ), and a smaller changes in the share of white-collars (panel 3), qualified and non-qualified blue collars (panel 4 and 5). Changes in the share of professionals reported in panel 2 seem to be uncorrelated with the change in the number of TBT faced by French firms.

In Table 1 we report some in-sample descriptive statistics. We divide the sample into firms that

\footnotetext{
${ }^{25} \mathrm{~A}$ full list and description of the French occupation categories defined by the French Statistics Institute (INSEE) can be found here: https://www.insee.fr/fr/information/2406153.

${ }^{26}$ The left panel of figure 1 shows only active STCs on TBT. So, when TBT concerns are solved there is a decrease in the number of active TBTs.

${ }^{27}$ In 2000-2001 many concerns raised by the EU were resolved. In particular, the sudden reduction in the number of active TBT concerns in 2000-2001 is due to the resolution of two big STCs raised by the EU against measures imposed by Egypt on 219 HS4 chapters and solved in 2000-2001 (see minute G/TBT/Notif.98.206).

${ }^{28}$ For all French firms in each HS 4-digit sector and year, we calculate the number of destination-product combinations covered by TBT, and afterward we compute the average across firms in each HS4-year combination. The horizontal axis of Figure 2 reports the average time change of such averages.
} 
Figure 1 - TBTs: total and share of exports

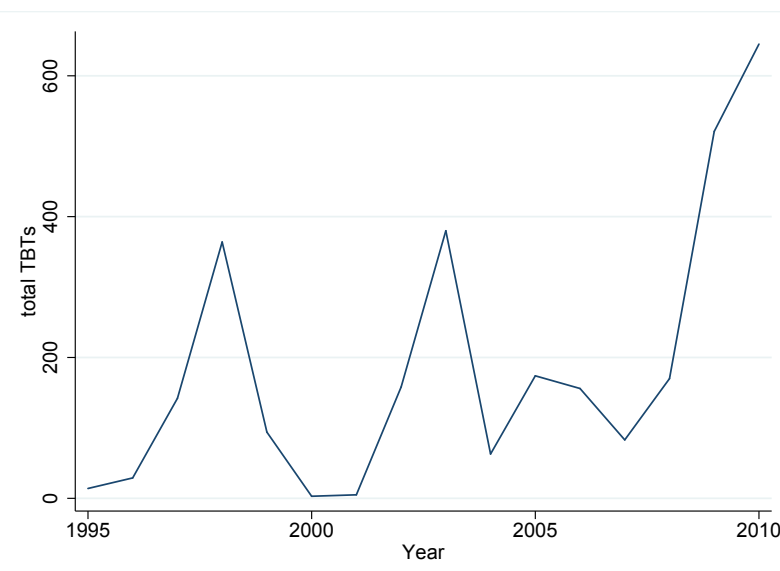

(a) Total Number of TBTs

Note: number of sector-destination pairs under ongoing EU-raised STCS on TBT.

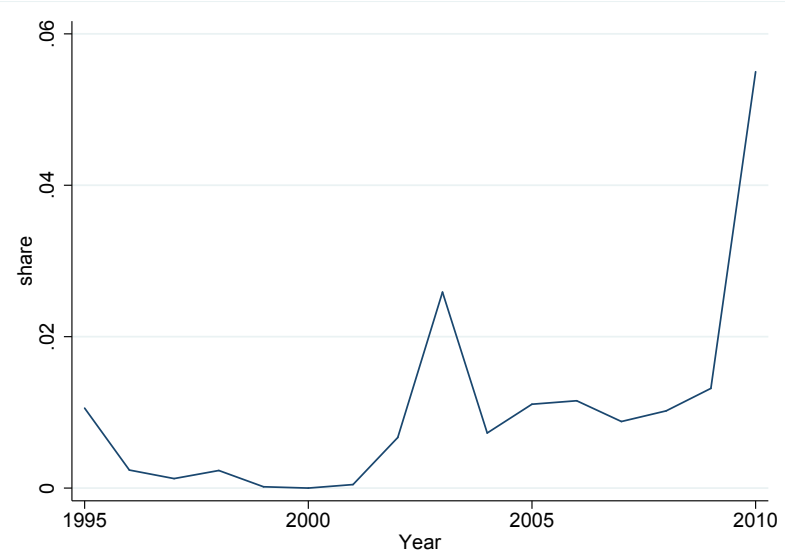

(b) Share of exports with TBTs

Note: share of total exports towards sector-destination with ongoing STC on TBT (coverage ratio).

Figure 2 - TBTs and changes in the within firm employment composition
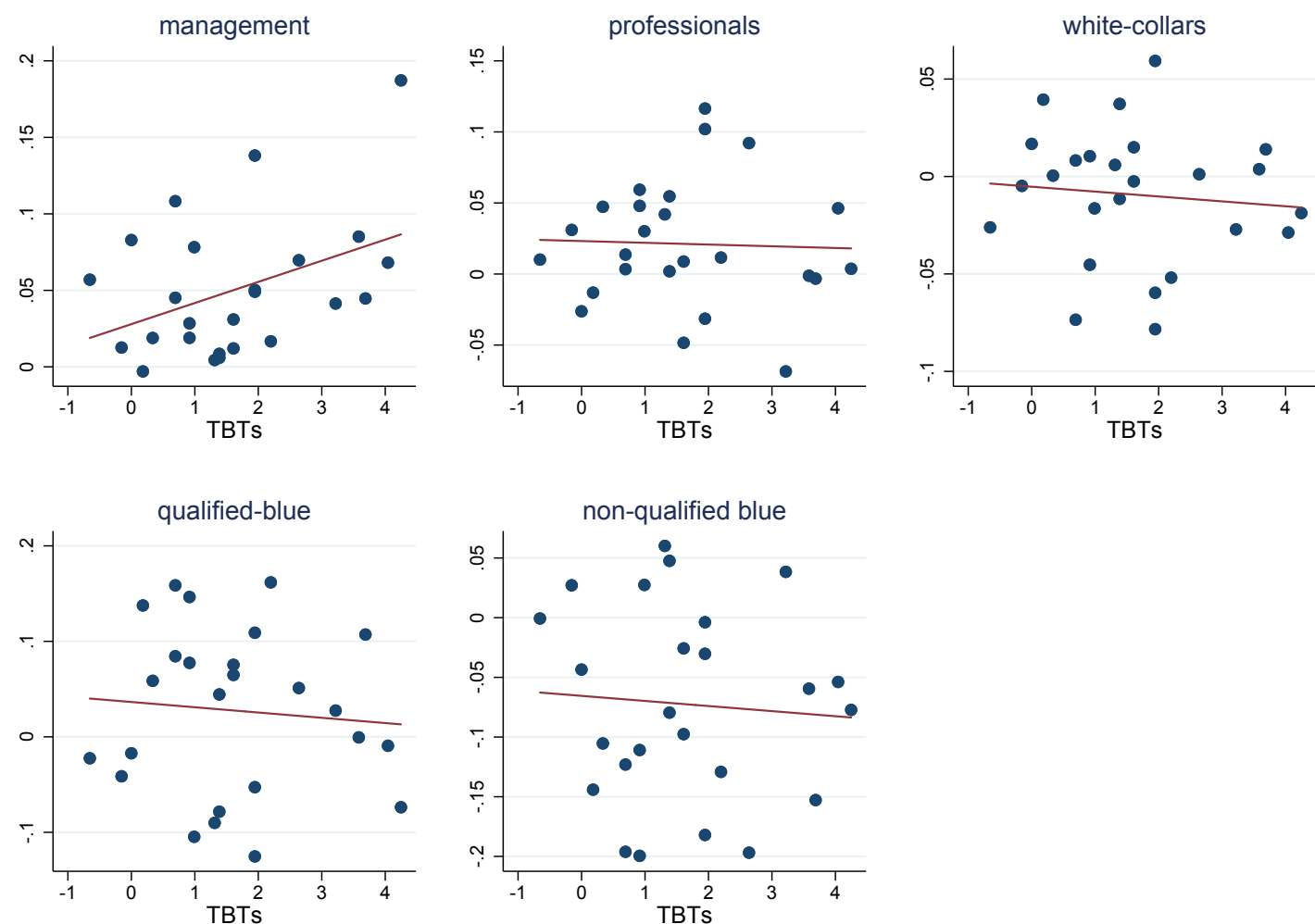

Source: Authors' calculations on DADS, WTO STCs and French Custom data. Note: in the vertical axis we report the change in the average share of employment (by type of occupation) across firms within a HS 4-digit sector. In the horizontal axis we report the change in the average number of TBTs faced by French firms over the period 1995-2010. Each point represents a 4-digit sector. Sectors without TBT or having zero change in TBT are not reported to the sake of readability (given the presence of firm fixed effects (subsuming sector fixed effects), these sectors do not contribute the the identification of our econometric results). 
serve sectors-destinations that have never been affected by Specific Trade Concern (last column of the table), and firms facing at least one TBT between the 1995 and 2010 (i.e. firms facing at least one TBT concern on one of its product-destination markets over the period). Firms experiencing at least one TBT concern face one average 1.76 TBT concerns. The second and third row of Table 1 show the number of firms and the percentage of firms in each column. As expected, firms facing STCs on TBT are the minority (12\% of the sample). The rest of the table, for the sample of affected and non-affected firms, shows: (i) the sectoral distribution, (ii) the average employment share by macro-occupation, and (iii) the average trade friction (tariff and distance) and export margins.

We observe a total of 30,777 firms: among them, we have 3271 firms affected at least once by a restrictive TBT between 1995 and $2010 .{ }^{29}$ When looking at the sectoral distribution of firms with concerns, as expected, the chemical industry is over-represented in the sample with TBTs. Looking at macro-occupations, the shares of managers and professionals are higher among firms with TBTs, while both the shares of qualified and non-qualified blue collars is lower. In general, firms in the TBT sample are serving relatively more distant destinations, face higher average tariffs, and export a wider portfolio of varieties than other exporting firms. This suggests that TBT-affected and TBT-free firms are substantially different in terms of observables and this, in turn, requires accurate econometric modeling to take care of potential unobserved heterogeneity. The next section discusses our empirical strategy.

\footnotetext{
${ }^{29}$ Although from French Custom data we observe more than one hundred thousands firms, the sample of firms shrinks considerably because we drop firms with less than 5 employees (as job composition does not make sense for micro-firms), and firms that do not appear in matched employer-employee DADS data (i.e. French exporters that are not obliged to declare their workforce composition).
} 
Table 1 - In-sample descriptive Statistics.

\begin{tabular}{lcc}
\hline & At least one TBT & TBT-free \\
\hline Average number of TBTs per affected firm & 1.76 & 0 \\
Firm/year observations & 3,271 & 27,504 \\
\% of firms & 11.9 & 88.10 \\
\hline Sectoral distribution (\%) & & \\
Manufacturing of food, beverages and tobacco & 12.91 & 7.04 \\
Manufacturing of of textiles and leather & 24.97 & 13.30 \\
Manufacture of wood, paper, publ./print & 1.7 & 10.33 \\
Chemical products, rubber, metals & 21.65 & 36.64 \\
Machinery and equipment & 9.77 & 10.62 \\
Manufacture of electrical and optical equipment & 21.65 & 11.40 \\
Transport equipment/furniture & 7.37 & 10.68 \\
\hline Occupations (\%) & & \\
Share of managers & 18.89 & 13.1 \\
Share of professionals & 23.51 & 20.18 \\
Share of white collars & 10.94 & 10.33 \\
Share of qualified blue collars & 29.15 & 33.94 \\
Share of non qualified blue collars & 17.31 & 21.95 \\
\hline Tariff & 0.11 & 0.075 \\
Market distance (km) & 14,574 & 9,582 \\
Number of market served & 22.48 & 7.87 \\
Number of varieties & 75.32 & 17.10 \\
\hline Observations & 5,118 & 161,260 \\
\hline
\end{tabular}

Source: DADS, WTO STCS and French Custom data for 1995 to 2010. 


\section{Empirical strategy}

Our basic empirical specification borrows from Fontagné et al. (2015) with the caveat that the impossibility to attribute workers to the production of a specific good for a specific export destination forces us to work at the firm/year level. Our preferred specification addresses endogeneity issues adopting an IV approach. We now present the set up and the instrumental variable strategy sequentially.

\subsection{Basic set up}

We estimate the following equation:

$$
y_{i, t, k}=\alpha_{i, k}+\gamma_{s, t, k}+\beta_{1, k} T_{B} T_{i, t-1}+\beta_{2, k} \text { Tariffs }_{i, t-1}+\varepsilon_{i, t, k}
$$

where $y_{i, t, k}$ is the share of the occupational category $k$ in the employment (total number of workers) of firm $i$ at time $t .{ }^{30}$ The term $\alpha_{i, k}$ is a firm $\times$ occupation fixed effect, and $\gamma_{s, t, k}$ is a set of (1-digit) sector $\times$ year dummies specific to occupation $k$. Tariffs $s_{i, t-1}$ measures the average tariff level faced by each French firm across its exported products and destinations, and aims at isolating the effect of technical barriers to trade from traditional tariffs. ${ }^{31}$ Specifically, we attach the tariff level faced by firm $i$ in each of its product-destination combinations, and then take the simple firm specific average tariff across products and destinations served by the firm.

The variable $T B T_{i, t-1}$ measures the number of Specific Trade Concerns on TBTs faced by the firm $i$ at time $t-1$, measured as the sum of the EU-raised TBT Specific Trade Concerns faced in all the products-markets combinations in which the firm exports. ${ }^{32}$ Therefore our coefficient of interest, $\beta_{1, k}$, measures the impact of the number of TBTs faced by the specific firm on the share of workers employed in occupation $k$. Notice that the variable $T B T_{i, t-1}$ varies both when a concern is raised (or solved) ${ }^{33}$ on a market in which the firm is already present, and when the firm enters or exits a market in which a concern exists. This raises an endogeneity concerns which is addressed (and discussed) in the next section. We run the above specification, separately for each occupation $k$, on the full sample of manufacturing exporting firms with more than 5 employees resulting from the merge between Custom and matched employer-employee data (see section 2 for more details on the estimation sample). We do not consider firms with less than 5 employees as micro firms do not have a complete spectrum of occupations and this

\footnotetext{
${ }^{30}$ Occupation groups are defined in section 2.2.

${ }^{31}$ We use effectively applied bilateral tariffs from MAcMap (CEPII) database (http://www . cepii.fr/CEPII/fr/ bdd_modele/presentation.asp?id=12)

${ }^{32}$ We keep the number of TBTs at $t-1$ as we assume that any adjustment in the workforce composition of firms takes some time to happen. By taking the lagged number of concerns faced by the firm reduces also the reverse causality issue.

${ }^{33}$ Since the $T B T_{i, t-1}$ variable captures both the imposition or the resolution of a TBT restrictive measure, its effect on the occupational composition has to be interpreted as symmetric.
} 
would inflate the dataset with zeros for many occupational categories. Also, we do not consider domestic firms in order to have a proper counterfactual, i.e. $T B T_{i, t-1}=0$ if the firm exports uniquely towards TBT-free destinations. Results from estimates on these samples are presented in section 4.1 .

Any time-invariant firm-specific factors - including average productivity, average firm size and managerial structure - affecting the share of workers employed in occupation $k$ is controlled for by the occupation-specific firm fixed effect $\alpha_{i, k}$. Namely, firm fixed effects also control for the average size of the firm. This is particularly relevant in our empirical strategy because large firms may export (on average) towards a wider set of destinations and thus face more TBT measures. Moreover, firms with good managerial structure and capabilities may opt for a larger set of destination markets, and therefore face a larger number of TBTs among destinations. Firm fixed effects, by controlling for the average managerial capability of the firm, purge our results from any managerial-related time-invariant confounding factor. The use of a within estimator also reduces reverse causality concerns, as any reverse causality argument must be valid in deviations from the occupation-specific firm average (rather than in levels) - see next section for a more detailed discussion. In all specifications we always include (1-digit) sectoryear dummies specific to occupation $k$ to control for any sector-time-occupation specific factor affecting the workforce composition of French firms. Our main objective here is to control for any time-varying technological shocks to occupation $k$ common to all firms in a given sector. Indeed, unobserved sector specific demand shocks may require an adjustment in the composition of the workforce of firms operating in the sector and will be controlled for by the fixed effect $\gamma_{s, t, k}$. Finally, any time-varying firm-specific shock that affects homogeneously all the workers' categories of the firm - i.e. that affects the employment level - is mechanically controlled for by having the share of a given worker category over total employment as dependent variable.

Even though our specification includes a rich set of fixed effects $\alpha_{i, k}$ and $\gamma_{s, t, k}$ that allow us addressing many potential sources of bias, there may be additional sources that we discuss in the next sub-section.

\subsection{Additional sources of bias and instrumental variable strategy}

First, one may worry about reverse causality. Due to political economy of trade barriers, one may argue that EU-raised Specific Trade Concerns may result from the lobbying activity of large skill-intensive French firms towards the EU commission. As discussed above, the rich set of fixed effects $\alpha_{i, k}$ and $\gamma_{s, t, k}$ included in equation (1) already considerably reduces this concern, as any reverse causality argument must be valid in deviation from the firm time-invariant average (i.e. deviations from the average firm's occupational composition affecting the change in the set of product-destination combinations under restrictive TBT). Yet, one may not exclude that firms whose skill-intensity grows with respect to the time-invariant average are better able to lobby the EU Commission to rise a STC on TBT. 
A second concern is that we risk not disentangling the effect that comes from an exogenous change in the number of TBTs faced by a given firm, and the endogenous firm's entry decision. Following a positive firm-level productivity shock, firms might at the same time become more skill-intensive and enter product-destination markets with TBTs, thus facing endogenously additional TBT measures. This might lead to the fallacious conclusion that firms coping with stringent TBTs upgrade the skill composition of their workforce. Insofar as the source of unobserved firm-level heterogeneity is time-invariant, this concern is fully addressed by the use of firm $\times$ occupation fixed-effects. However, it is still possible that time-varying firm-specific shocks induce firms to endogenously self-select into specific destination markets. ${ }^{34}$

For these reasons, we complement the specification laid out in equation (1) with an IV strategy aimed at addressing the remaining concerns. In building the IV for TBTs we benefit from the rich information contained in the STC data. As a source of exogenous variation in the number of STCs on TBT faced by French firms, we use the STCs raised by non-EU countries, which are plausibly orthogonal to any time-varying non observable shocks hitting French firms.

More specifically, we instrument our main dependent variable, i.e. the number of EU-raised Specific Trade Concerns on TBT faced by the specific firm $i$ at time $t-1$, with the number of STCs raised by the rest of the world (extra-EU) on the sample of product-destination combinations served by firm $i$ at time $t-1$. Our IV, therefore, varies at the firm level, very much as the endogenous explanatory variable $T B T_{i, t-1}$.

The rationale for this IV is that STC raised by non-EU countries are unlikely to be affected by any (time-varying) characteristics of French firms. More formally, the identification assumption is that STC raised by non-EU countries are orthogonal to any firm-level shocks, and in particular to the workforce composition of a specific French firm (conditioning on firms and sector-by-year effects specific to occupation $k$ ). Under this assumption, we are able to capture the exogenous variation of the EU-TBTs that is not due to time-varying firm-level shocks that may induce entry in specific destinations or trigger lobbying activities. We are therefore confident that our IV estimates identify the causal effect of TBTs on the composition of the workforce of French firms.

As widely recognized in the previous literature, also tariffs cannot be considered as purely exogenous in a firm-specific regression if a firm has sufficient power to influence the trade policy of the destination country, or if such a country reacts to a firm specific import shock by raising tariffs. ${ }^{35}$ For this reason, we instrument also the average tariffs faced by the specific French firm to further reduce any remaining endogeneity concern. The IV for tariff is based on the tariff

\footnotetext{
${ }^{34}$ Finally, one may worry about the residual endogeneity of TBTs if unobserved HS 4-digit specific shocks (as opposed to shocks at the 1-digit sector level controlled for by $\gamma_{s, t, k}$ ) affect both the workforce composition of firms and the probability of observing a TBT at destination.

${ }^{35}$ The endogeneity concern is particularly remote when the effectively applied tariff corresponds to the applied MFN rate. Indeed, MFN applied tariffs are not set to face imports from a specific country.
} 
level faced by extra-EU countries in exporting toward a given destination-sector market. For each destination $j$ and sector $s$ we calculate the average import tariff imposed towards extra-EU exporting countries ( $\operatorname{Tariffs}_{s, j}^{n o n-E U}$ ). We instrument the firm's average tariff using the average tariff imposed by firm's destinations towards non-EU exporters:

$$
\operatorname{Tariffs}_{i, t-1}^{I V}=\frac{1}{S} \frac{1}{J} \sum_{s j} \operatorname{Tariffs}_{s, j, t-1}^{n o n-E U}
$$

where $S$ and $J$ stand respectively for total number of sectors $s$ and destination $j$ served by firm $i$ at time $t-1$. The tariff level imposed by destination $j$ on sector $s$ toward a non-EU exporter can be plausibly considered exogenous and affecting the occupation composition of firm $i$ only through its effect on $T_{\text {arif }} f_{i, t-1}$ (exclusion restriction). Notice that also for tariffs, the instrument varies at the firm level as the endogenous variable. We run the IV specification, separately for each occupation $k$, on the full sample of exporting manufacturing firms as described in section 2; results from IV estimates are presented in section 4.1.

\section{Results}

\subsection{The effect of TBTs on the occupational composition of firms}

We estimate equation (1) on all manufacturing companies that have exported at least once between 1995 and 2010, therefore using a sample of over 30,000 manufacturing companies. Table 2 reports results from separate regressions of equation (1) for each occupational category. In particular, we look at the effect of TBT on the share of managers, professionals, white collars, qualified and non-qualified blue collars in the firm's total workforce. The first column shows the fixed effect OLS estimation, while the second column shows the results from the fixed effects IV estimation, where both technical barriers to trade and tariffs are instrumented as explained in the previous section. The dependent variable is the share of full-time equivalent employees in occupation $k$ over the total workforce of the exporting firm. The measure of TBTs is the (1-year lagged) total number of concerns (HS4-destination pairs) faced by each company while tariffs are measured by the average level of tariffs faced by the firm among the product-destination served (also 1-year lagged). As indicated in equation 1 , all regressions include firm fixed effects and the interaction between (1-digit) sector dummies and year dummies.

Table 2 shows strong and significant results for the managerial layer, in both specifications: an additional TBT concern in one of the markets where the firm was present in the previous year, increases the share of managers by 0.3 percentage points. The fact that IV estimates are also positive and significant is reassuring as it implies that fixed effects OLS estimates are not simply capturing entry in difficult markets (i.e. markets characterized by high TBTs) accompanied by an increase the share of managers, by firms hit by a positive (unobservable) shock. The point estimate of the TBT coefficient is three times bigger ( 1 percentage points) when estimated via 
IVs. This can be interpreted in light of the political economy concern discussed above. If firms that are not able to comply with new TBT (less manager-intensive firms) are more likely to lobby for raising a STCs at the WTO (implying a negative correlation between the share of managers and the number of TBT) then the OLS coefficient would be downward biased. Consistent with this argument, when endogeneity is addressed, the point estimate becomes larger. The table also reports the main first-stage coefficients, i.e. the coefficient of the instrument for TBT of the first-stage TBT equation and the coefficient of the instrument for tariffs of the first-stage Tariff equation, along with the Kleibergen-Paap Wald test. Not surprisingly, the first-stage coefficients of the instruments are highly significant and there is no evidence of instruments being weak.

The average increase in the share of managers comes with a significant decrease in the shares of professionals, qualified and non-qualified blue collars, suggesting a strong impact of stringent TBTs on the workforce composition of French exporters. In particular, an additional TBT concern in one of the product-destination combinations served by firm $i$ at time $t-1$ decreases the share of professionals by 0.3 percentage points, and the share of qualified and non-qualified blue collar jobs respectively by 0.3 and 0.2 percentage points. In other words, the increase in the share of managerial occupations is compensated by the reduction in professional and blue collar occupations. All in all, and in line with the previous literature highlighting skilled workers nature of fixed export costs, an increase in the TBT-induced fixed export cost is faced by an increase in the firm's skilled intensive managerial occupations.

\subsection{Top exporters serving more than 6 markets}

As discussed above, firms may endogenously self-select into destinations having large or small number of STCs on TBT. For instance, following a positive productivity shock (notice that the average productivity of the firm is captured by fixed effects), a firm may decide to enter a promising but costly (TBT-imposing) product-destination market. Our IV approach takes care of this concern under the assumption that the instrument is uncorrelated with firm-level productivity shocks. Another way to (imperfectly) address this concern, is using a sub-sample of firms with an arguably homogeneous productivity level, and probably similar productivity pattern. To this end, in Table 3 we include only firms that serve more than 6 markets (the 95th percentile of the distribution of markets served by firms on average over the period), and thus arguably having a homogeneously high productivity level. ${ }^{36}$ In this sub-sample of firms the share of managers is on average higher than for full sample of firm used on our baseline (respectively $20 \%$ for firms with at least one TBT and $15 \%$ for firms without TBTs). All the other occupation shares are similar to the ones observed in the whole manufacturing sample. Results reported in Table 3 confirm our baseline findings, showing that, also for the

\footnotetext{
${ }^{36}$ In moving from full sample to multi-destination firms (i.e. those with more than 6 destinations) the number of observations shrinks by $66 \%$ as we loose small firms with very incomplete time span and firms exporting to a very small set of destinations.
} 
Table 2 - Effect of TBTs on firm layers (manufacturing sector): full sample

\begin{tabular}{lcc}
\hline & \multicolumn{2}{c}{ TBT } \\
\cline { 2 - 3 } Share of Managers: & $\mathrm{FE}$ & $\mathrm{IV}+\mathrm{FE}$ \\
TBTs & $0.003^{* * *}$ & $0.010^{* * *}$ \\
& $(0.000)$ & $(0.001)$ \\
Tariffs & $-0.006 * *$ & -0.003 \\
& $(0.003)$ & $(0.005)$
\end{tabular}

Share of Professionals:

TBTs

$\begin{array}{cc}-0.001 & -0.003 * * * \\ (0.000) & (0.001) \\ 0.002 & 0.002 \\ (0.004) & (0.007)\end{array}$

Share of White Collars:

TBTs

$\begin{array}{cc}0.001^{*} & -0.000 \\ (0.000) & (0.000) \\ 0.00)^{* * *} & 0.010^{*} \\ (0.003) & (0.006)\end{array}$

Share of Qualified Blue Collars:

TBTs

$\begin{array}{cc}-0.000 & -0.003^{*} \\ (0.000) & (0.001) \\ -0.001 & 0.000 \\ (0.006) & (0.010)\end{array}$

Share of Non Qualified Blue Collars:

TBTs

Tariffs

IV: TBT $0.451 * * *$

IV: Tariffs $0.608 * * *$

Observations

First stage Kleibergen-Paap rk Wald F statistic

Number of firms

Firm FE\& Sector $\times$ Year FE

$\begin{array}{cc}189,981 & 138,854 \\ & 159.71 \\ 29,990 & 22,275 \\ \text { YES } & \text { YES }\end{array}$

Note: Standard errors in parentheses clustered by firm. The middle panel reports the main first-stage coefficients: IV: TBT is the coefficient on the instrument for TBT of the first-stage TBT equation; IV: Tariff is the coefficient of the instrument for tariffs of the first-stage Tariff equation. ${ }^{* * *} p<0.01 ; * * p<$ $0.05 ; * p<0.1$. $* * * p<0.01 ; * * p<0.05 ; * p<0.1$. Source: DADS, WTO STCs and French Custom data for 1995 to 2010. 
most productive firms exporting in at least 6 markets, the presence of stringent standards at destination drives companies towards a new organizational structure relying on a higher share of managers and lower share of professionals (the coefficients on qualified and non-qualified blue collar jobs are similar to the baseline estimation but imprecisely estimated). ${ }^{37}$

Table 3 - Effect of TBTs on firm layers (manufacturing sector). Top exporters serving more than 6 markets.

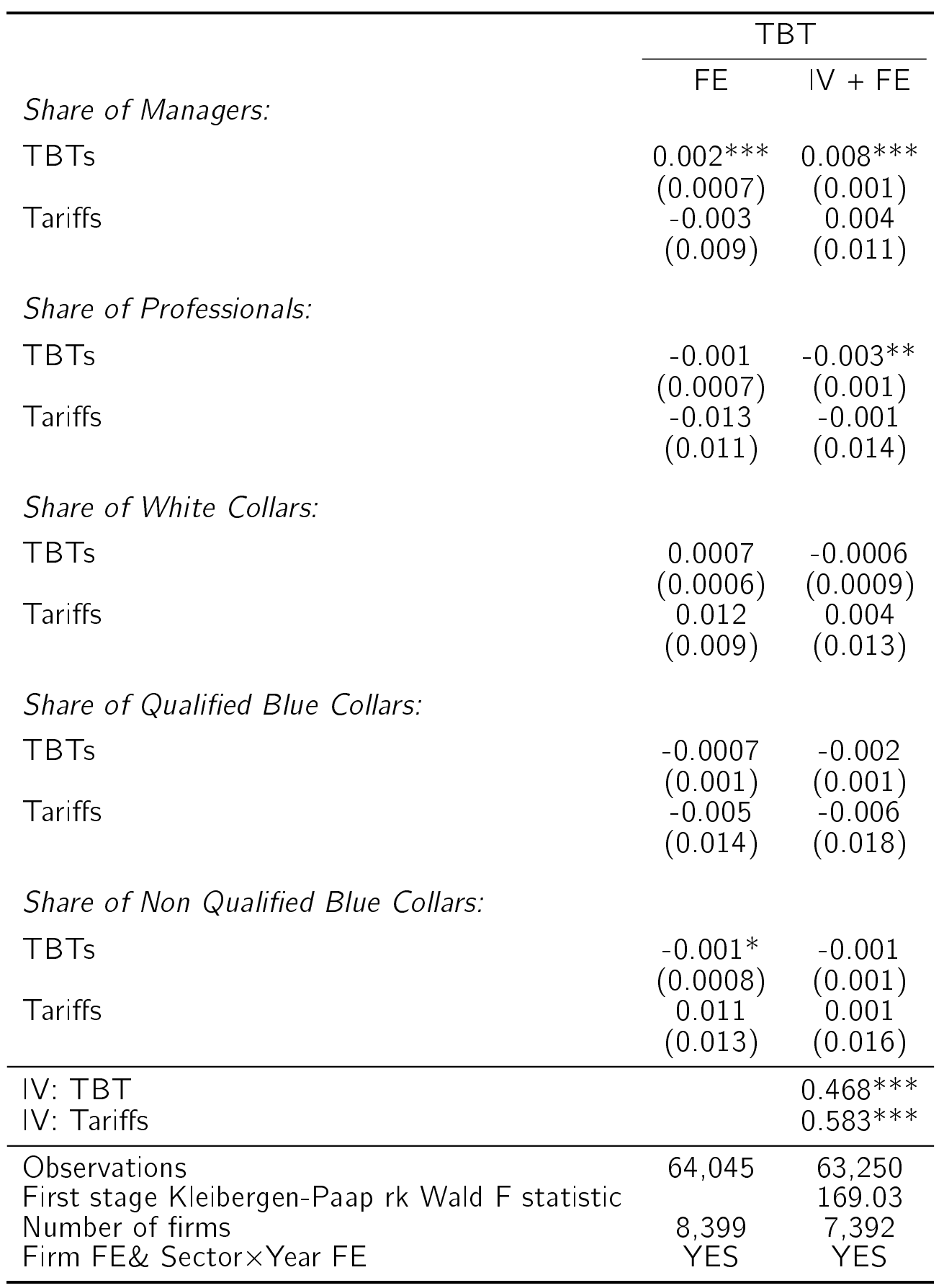

Note: Standard errors in parentheses clustered by firm. The middle panel reports the main first-stage coefficients: IV: TBT is the coefficient on the instrument for TBT of the first-stage TBT equation; IV: Tariff is the coefficient of the instrument for tariffs of the first-stage Tariff equation. $* * * p<$ $0.01 ; * * p<0.05 ; * p<0.1$. $* * * p<0.01 ; * * p<0.05 ; * p<0.1$. Source: DADS, WTO STCS and French Custom data for 1995 to 2010.

\footnotetext{
${ }^{37}$ The table also reports the first-stage coefficients of the instruments and the Kleibergen-Paap Wald $F$ test that shows no evidence of weak instruments problems.
} 


\subsection{Managerial sub-layers}

The key result so far is the positive effect of TBTs on the share of managers within the firm. However, this macro-occupational group covers a wide range of occupations (from 21 to 38 PCS French occupational code), such as directors, sales managers, engineers etc. So, testing the effect of TBTs on each sub-layer belonging to the managerial layer may help uncovering the specific channel driving the baseline results discussed above. We, therefore, split the managerial layer into 4 finer sub-layers: (i) CEOs; ${ }^{38}$ (ii) sale executives; (iii) engineers and (iv) other top managers (lawyers, doctors, professors, etc.). ${ }^{39}$

The share of CEOs represents on average (as full time equivalent) the $3.4 \%$ of the total employment of the firm, the sale executives the $6.8 \%$, the engineers the $4.7 \%$ and finally other top managers account for the $1.2 \%$ of total employment. In Table (4) we report the share of these categories for firms facing TBTs and other TBT-free firms. It clearly emerges that, on average, firms facing at least one TBT have higher shares of engineers. This is probably due to the fact that engineers are needed to adapt the product to a foreign technical standard and overcome the fixed export cost implied by the presence of a TBT.

Table 4 - Share of managers in managerial sub-layers

\begin{tabular}{lcc}
\hline & At least one TBT & TBT-free \\
\hline Occupations (\%) & & \\
Share of CEOs & 1.7 & 2.3 \\
Share of sales executives & 6.4 & 4.3 \\
Share of engineers & 10.3 & 5.8 \\
Share of other managers & 0.3 & 0.6 \\
\hline
\end{tabular}

Source: DADS, WTO STCs and French Custom data for 1995 to 2010.

In Table 5 we show baseline specification results on each of the occupation category composing the managerial group. From Table 5 it emerges that the positive effect we observe in Table 2 on managers is mainly driven by a positive effect on both the share of engineers and the share of sales executives. Facing one additional TBT would increase the share of engineers by 0.6 percentage points and the share of sales executives by 0.3 percentage points (see IV specification in column 2). Firms facing an additional TBT have to adapt their products to meet the technical standard; and engineers are the most needed occupations to this end. The result on the CEOs is significant when estimated via IV, with TBT increasing the share of heads by 0.1 percentage point.

\footnotetext{
${ }^{38}$ In the French occupation classification the $C S=2$ refers to "Chef d'entreprise salarié" which is loosely translated here as CEO. For simplicity we keep this definition of CEO in what follows with the disclaimer of imperfect translation.

${ }^{39}$ We divide the category management into the following categories: CEOs: $C S=2$; Sales Executives: $C S=37$; Engineers: $C S=38$ and Other professionals: $C S=31-33-34-35$.
} 
Table 5 - Effect of TBTs on managerial sub-layers (manufacturing sector): full sample

\begin{tabular}{|c|c|c|}
\hline \multirow[b]{2}{*}{ Share of CEOs: } & \multicolumn{2}{|c|}{ A.TBT } \\
\hline & FE & $\mathrm{IV}+\mathrm{FE}$ \\
\hline $\begin{array}{l}\text { TBTs } \\
\text { Tariffs }\end{array}$ & $\begin{array}{c}-0.0001 \\
(0.0002) \\
0.001 \\
(0.001)\end{array}$ & $\begin{array}{c}0.001 * * * \\
(0.0004) \\
0.004 \\
(0.003)\end{array}$ \\
\hline Share of Sales Executives: & & \\
\hline $\begin{array}{l}\text { TBTs } \\
\text { Tariffs }\end{array}$ & $\begin{array}{l}0.0009^{*} \\
(0.0005) \\
-0.004^{*} \\
(0.002)\end{array}$ & $\begin{array}{c}0.003^{* * *} \\
(0.001) \\
-0.005^{*} \\
(0.003)\end{array}$ \\
\hline Share of Engineers: & & \\
\hline $\begin{array}{l}\text { TBTs } \\
\text { Tariffs }\end{array}$ & $\begin{array}{c}0.002 * * * \\
(0.0005) \\
-0.003 * \\
(0.002)\end{array}$ & $\begin{array}{c}0.006 * * * \\
(0.001) \\
-0.003 \\
(0.003)\end{array}$ \\
\hline Share of Other Top Managers: & & \\
\hline $\begin{array}{l}\text { TBTs } \\
\text { Tariffs }\end{array}$ & $\begin{array}{c}-0.0002 * * \\
(0.0001) \\
-0.0003 \\
(0.0009)\end{array}$ & $\begin{array}{c}-0.0005^{* * *} \\
(0.0002) \\
0.0013 \\
(0.001)\end{array}$ \\
\hline $\begin{array}{l}\text { IV: TBT } \\
\text { IV: Tariff }\end{array}$ & & $\begin{array}{l}0.451 * * * \\
0.608 * * *\end{array}$ \\
\hline $\begin{array}{l}\text { Observations } \\
\text { First stage Kleibergen-Paap rk Wald F statistic } \\
\text { Number of firms } \\
\text { Firm FE\& Sector } \times \text { Year FE }\end{array}$ & $\begin{array}{c}189,981 \\
29,990 \\
\text { YES }\end{array}$ & $\begin{array}{c}138,854 \\
159.71 \\
22,275 \\
\text { YES }\end{array}$ \\
\hline
\end{tabular}

Note: Standard errors in parentheses clustered by firm. The middle panel reports the main first-stage coefficients: IV: TBT is the coefficient on the instrument for TBT of the first-stage TBT equation; IV: Tariff is the coefficient of the instrument for tariffs of the first-stage Tariff equation. $* * * p<0.01 ; * * p<$ $0.05 ; * p<0.1$. ${ }^{* * *} p<0.01 ; * * p<0.05 ; * p<0.1$. Source: DADS, WTO STCs and French Custom data for 1995 to 2010.

We next move to the sample of top exporters serving more than 6 markets. In this sub-sample of firms the share of engineers is on average higher than for full sample of firm used on our baseline (respectively $11 \%$ for firms with at least one TBT and $7 \%$ for firms without TBTs). All the other shares are similar to the ones observed in the whole manufacturing sample. Regression results reported in Table 6 confirm the findings in the full sample, with stringent TBTs implying an increase in the share of engineers and CEOs needed to comply with the new technical standard at destination. 
Table 6 - Effect of TBTs on managerial sub-layers (manufacturing sector). Top exporters serving more than 6 markets.

\begin{tabular}{|c|c|c|}
\hline \multirow[b]{2}{*}{ Share of CEOs: } & \multicolumn{2}{|c|}{ TBT } \\
\hline & $\mathrm{FE}$ & $\mathrm{IV}+\mathrm{FE}$ \\
\hline $\begin{array}{l}\text { TBTs } \\
\text { Tariffs }\end{array}$ & $\begin{array}{c}-0.0001 \\
(0.0002) \\
0.007 \\
(0.005)\end{array}$ & $\begin{array}{c}0.0005^{*} \\
(0.0003) \\
0.009 \\
(0.006)\end{array}$ \\
\hline Share of Sales Executives: & & \\
\hline $\begin{array}{l}\text { TBTs } \\
\text { Tariffs }\end{array}$ & $\begin{array}{l}0.0003 \\
(0.0005) \\
-0.005 \\
(0.006)\end{array}$ & $\begin{array}{l}0.0014 \\
(0.001) \\
-0.0001 \\
(0.007)\end{array}$ \\
\hline Share of Engineers: & & \\
\hline $\begin{array}{l}\text { TBTs } \\
\text { Tariffs }\end{array}$ & $\begin{array}{c}0.002 * * * \\
(0.0006) \\
-0.004 \\
(0.005)\end{array}$ & $\begin{array}{l}0.007 * * * \\
(0.001) \\
-0.005 \\
(0.005)\end{array}$ \\
\hline Share of Other Top Managers: & & \\
\hline $\begin{array}{l}\text { TBTs } \\
\text { Tariffs }\end{array}$ & $\begin{array}{c}-0.0002 * \\
(0.0001) \\
-0.001 \\
(0.002)\end{array}$ & $\begin{array}{c}-0.0005 * * * \\
(0.0002) \\
-0.0001 \\
(0.003)\end{array}$ \\
\hline $\begin{array}{l}\text { IV: TBT } \\
\text { IV: Tariff }\end{array}$ & & $\begin{array}{l}0.468 * * * \\
0.583 * * *\end{array}$ \\
\hline $\begin{array}{l}\text { Observations } \\
\text { First stage Kleibergen-Paap rk Wald F statistic } \\
\text { Number of firms } \\
\text { Firm FE\& Sector } \times \text { Year FE }\end{array}$ & $\begin{array}{l}64,045 \\
8,399 \\
\text { YES }\end{array}$ & $\begin{array}{l}63,250 \\
169.03 \\
7,392 \\
\text { YES }\end{array}$ \\
\hline
\end{tabular}

Note: Standard errors in parentheses clustered by firm. The middle panel reports the main first-stage coefficients: IV: TBT is the coefficient on the instrument for TBT of the first-stage TBT equation; IV: Tariff is the coefficient of the instrument for tariffs of the first-stage Tariff equation. $* * * p<0.01 ; * * p<$ $0.05 ; * p<0.1$. $* * * p<0.01 ; * * p<0.05 ; * p<0.1$. Source: DADS, WTO STCs and French Custom data for 1995 to 2010.

\subsection{The effect of TBTs on the probability to add layers}

The increase in the occupational composition of French firms may come along with a change in the hierarchies within the firm. Indeed, in line with the literature exploring how firms (re)organize production in hierarchies to economize on their use of knowledge (Garicano (2000); Caliendo and Rossi-Hansberg (2012); Rossi-Hansberg et al. (2020); Guadalupe and Wulf (2010)), it may be the case that the increase in the skill-intensive fixed export cost implied by a new standard at destination is faced by the ad - hoc introduction of a hierarchical layer in the firm. Therefore, in this section we also test if the increasing complexity faced by firms in export markets has an impact on the number of hierarchical layers in the organization of the firm, i.e. the extensive 
vertical margin of the organizational structure.

Table 7 shows regression results both from OLS and 2SLS fixed effects models (along the lines of the model in equation (1)) but using, in turn, three different dependent variables: $(i)$ the total number of hierarchical layers in the firm, (ii) the probability of adding a sub-layer among the top management positions (sale executives, engineers and other top managers), and (iii) the probability of adding a sub-layer among heads of enterprise (including CEOs or firm directors). ${ }^{40}$ Unfortunately, we could not replicate exactly the same dependent variable as in Guadalupe and Wulf (2010) because we do not have information on who is reporting directly to the CEO and on who covers division manager positions in the firm.

Results reported in Table (7) show that TBTs have a positive but imprecisely estimated effect on the total number of layers (t-stat 1.7, see column 2 in Table 7). Conversely, TBT have a positive and significant effect (2SLS specification) on the probability of adding a new sub-layer at the top of the firm's hierarchy (CEOs). We can therefore conclude that the imposition of a new TBT does not change the number of layers in the firm but positively affects the probability of adding a new sub-layer at CEO level. In particular, TBTs make firms more likely to add a layer at the CEO level by 1.1 percentage points. By combining estimation results on the total number of layers in the firm with the probability of adding a new sub-layer at CEO level, we may conclude that the imposition of a new TBT among firm's markets pushes the firm to increase the number of sub-layers at the top of the hierarchy and reduce the number of layer at the bottom of the hierarchy in order to keep constant the number of layers in the firm.

\footnotetext{
${ }^{40}$ We grouped sales executives, engineers and other top-managers in a single category for the sake of table readability. The effect of TBT on each specific managerial job is not statistically significant (results available upon request).
} 
Table 7 - Effect of TBTs on the firm organization (manufacturing sector)

\begin{tabular}{|c|c|c|}
\hline \multirow[b]{2}{*}{ Total layers: } & \multicolumn{2}{|c|}{ TBT } \\
\hline & FE & $\mathrm{IV}+\mathrm{FE}$ \\
\hline $\begin{array}{l}\text { TBTs } \\
\text { Tariffs }\end{array}$ & $\begin{array}{c}0.000 \\
(0.003) \\
0.024 \\
(0.025)\end{array}$ & $\begin{array}{c}0.012 \\
(0.007) \\
-0.018 \\
(0.04)\end{array}$ \\
\hline Probability of adding a top manager: & & \\
\hline $\begin{array}{l}\text { TBTs } \\
\text { Tariffs }\end{array}$ & $\begin{array}{l}-0.000 \\
(0.001) \\
-0.022 \\
(0.014)\end{array}$ & $\begin{array}{l}-0.004 \\
(0.002) \\
-0.028 \\
(0.023)\end{array}$ \\
\hline Probability of adding a CEO: & & \\
\hline $\begin{array}{l}\text { TBTs } \\
\text { Tariffs }\end{array}$ & $\begin{array}{l}-0.000 \\
(0.003) \\
0.041^{* *} \\
(0.019)\end{array}$ & $\begin{array}{c}0.011^{*} \\
(0.006) \\
0.022 \\
(0.03)\end{array}$ \\
\hline $\begin{array}{l}\text { IV: TBT } \\
\text { IV: Tariff }\end{array}$ & & $\begin{array}{l}0.451 * * * \\
0.608 * * *\end{array}$ \\
\hline $\begin{array}{l}\text { Observations } \\
\text { First stage Kleibergen-Paap rk Wald F statistic } \\
\text { Number of firms } \\
\text { Firm FE\& Sector } \times \text { Year FE }\end{array}$ & $\begin{array}{l}189,996 \\
29,990 \\
\text { YES }\end{array}$ & $\begin{array}{l}138,861 \\
159.71 \\
22,275 \\
\text { YES }\end{array}$ \\
\hline
\end{tabular}

Note: Standard errors in parentheses clustered by firm. The middle panel reports the main firststage coefficients: IV: TBT is the coefficient on the instrument for TBT of the first-stage TBT equation; IV: Tariff is the coefficient of the instrument for tariffs of the first-stage Tariff equation. $* * *$ $p<0.01 ; * * p<0.05 ; * p<0.1$. *** $p<0.01 ; * * p<0.05 ; * p<0.1$. Source: DADS, WTO STCS and French Custom data for 1995 to 2010. 


\section{Concluding remarks}

This paper provides an empirical assessment of the effect of stringent technical standards at destination on the occupational composition of exporting firms. Making use of detailed firm level matched employer-employee data for the universe of French exporters, with information on exports by destination country and Specific Trade Concern (STC) data released by the WTO on restrictive TBTs, we identify the effect of such NTMs exploiting (unexpected) changes in trade restrictive TBTs imposed on EU exports by importing countries.

We find that TBTs, by rising the fixed costs associated to serve a given destination (adaptation cost), change the skill composition of firms' workforce towards skill intensive occupations. In particular, one additional restrictive TBT among the destination-product combinations served by the firm increases the share of managers by one percentage point, and reduces the share of professional, qualified and non-qualified blue collar jobs respectively by $0.3,0.3$ and 0.2 percentage points. Among the managerial occupations, the share of engineers in production is the most affected by the imposition of restrictive TBT at destination. This supports the idea that new stringent technical standard at destination forces the firm to adapt workforce composition by hiring workers (engineers) able to adapt the product to the new standard. 


\section{References}

Acemoglu, D., D. Autor, D. Dorn, G. H. Hanson, and B. Price (2016). Import competition and the great us employment sag of the 2000s. Journal of Labor Economics 34(S1), S141-S198.

Autor, D., D. Dorn, and G. H. Hanson (2013). The china syndrome: Local labor market effects of import competition in the united states. American Economic Review 103(6), 2121-2168.

Bas, M. and P. Bombarda (2013). Chinese Trade Reforms, Market Access and Foreign Competition: the Patterns of French Exporters. World Bank Economic Review vol. 27(1). First published online June 25, 2012.(1), 80-108.

Bernard, A. B., S. J. Redding, and P. K. Schott (2011). Multiproduct firms and trade liberalization. The Quarterly Journal of Economics 126(3), 1271-1318.

Beverelli, C., M. Boffa, and A. Keck (2019, November). Trade policy substitution: theory and evidence. Review of World Economics (Weltwirtschaftliches Archiv) 155(4), 755-783.

Biscourp, P. and F. Kramarz (2007). Employment, skill structure and international trade: Firmlevel evidence for france. Journal of International Economics 72(1), 22 - 51.

Brambilla, I., D. Lederman, and G. Porto (2012). Exports, export destinations and skills. American Economic Review 102, 3406-3438.

Bresnahan, T. F., E. Brynjolfsson, and L. M. Hitt (2002, 02). Information Technology, Workplace Organization, and the Demand for Skilled Labor: Firm-Level Evidence*. The Quarterly Journal of Economics 117(1), 339-376.

Burstein, A. and J. Vogel (2017). International Trade, Technology, and the Skill Premium. Journal of Political Economy 125(5), 1356-1412.

Caliendo, L., F. Monte, and E. Rossi-Hansberg (2015). The anatomy of French production hierarchies. Journal of Political Economy 123(4), 809-852.

Caliendo, L. and E. Rossi-Hansberg (2012). The impact of trade on organization and productivity. Quarterly Journal of Economics 127(3), 1393-1467.

Chaney, T. (2008). Distorted gravity: The intensive and extensive margins of international trade. American Economic Review 98(4), 1707-0721.

Crivelli, P. and J. Groeschl (2016, March). The Impact of Sanitary and Phytosanitary Measures on Market Entry and Trade Flows. The World Economy 39(3), 444-473.

Feenstra, R. C., H. Ma, and Y. Xu (2019, September). US exports and employment. Journal of International Economics 120, 46-58.

Fontagné, L., O. Gianluca, and P. Roberta (2020). Making (Small) Firms Happy? The Heterogeneous Effect of Trade Facilitation Measures. Review of International Economics forthcoming.

Fontagné, L. and G. Orefice (2018). Let's try next door: Technical barriers to trade and multi-destination firms. European Economic Review 101, 643-663.

Fontagné, L., G. Orefice, R. Piermartini, and N. Rocha (2015). Product standards and margins of trade: Firm-level evidence. Journal of International Economics 97(1), 29-44.

Fontagné, L., A. Secchi, and C. Tomasi (2018). Exporters product vectors across markets. European Economic Review 110, 150-180.

Francois, J., M. Manchin, and H. Norberg (2011). European perspectives on NTM and tariff liberalization. Technical report, ESRI Discussion Paper, Series.

Friedrich, B. U. (2020). Trade Shocks, Firm Hierarchies, and Wage Inequality.

Garicano, L. (2000). Hierarchies and the organization of knowledge in production. Journal of Political Economy 108(5), 874-904.

Goos, M., A. Manning, and A. Salomons (2014). Explaining job polarization: Routine-biased technological change and offshoring. American Economic Review 104(8), 2509-2526. 
Grundke, R. and C. Moser (2019). Hidden protectionism? evidence from non-tariff barriers to trade in the united states. Journal of International Economics 117, $143-157$.

Guadalupe, M., H. Li, and J. Wulf (2014, April). Who Lives in the C-Suite? Organizational Structure and the Division of Labor in Top Management. Management Science 60(4), 824844.

Guadalupe, M. and J. Wulf (2010, October). The Flattening Firm and Product Market Competition: The Effect of Trade Liberalization on Corporate Hierarchies. American Economic Journal: Applied Economics 2(4), 105-127.

Harrigan, J. and A. Reshef (2015). Skill-biased heterogeneous firms, trade liberalization and the skill premium. Canadian Journal of Economics 48(3), 1024-1066.

Harrigan, J., A. Reshef, and F. Toubal (2020). The march of the techies: Job polarization within and between firms. Research Policy, 104008.

Keller, W. and H. Utar (2016). International trade and job polarization: Evidence at the workerlevel. Technical report, National Bureau of Economic Research.

Matsuyama, K. (2007). Beyond icebergs: Towards a theory of biased globalization. Review of Economic Studies 74, 237-53.

Maurin, E., M. Thoenig, and D. Thesmar (2002). Globalization and the demand for skill: an export based channel. Centre for Economic Policy Research (CEPR) working paper, 3406.

Mayer, T., M. J. Melitz, and G. I. Ottaviano (2014). Market size, competition, and the product mix of exporters. American Economic Review 104(2), 495-536.

Orefice, G. (2017). Non-tariff measures, specific trade concerns and tariff reduction. The World Economy 40(9), 1807-1835.

Rossi-Hansberg, E., L. Caliendo, G. Mion, and L. D. Opromolla (2020). Productivity and organization in portuguese firms. Journal of Political Economy forthcoming.

Sforza, A. (2019). Shocks and the organization of the firm: Who pays the bill? Mimeo University of Bologna.

UNCTAD (2019). International classification of non-tariff measures. Technical report, UNCTAD.

Van Reenen, J., N. Bloom, K. Manova, S. Teng Sun, and Z. Yu (2020). Trade and Management. CEP Discussion Paper No 1553.

WTO (2012). World trade report 2012. trade and public policies: A closer look at non-tariff measures in the 21st century. Technical report, World Trade ORganization.

Yeaple, S. (2005). A simple model of firm heterogeneity, international trade, and wages. Journal of International Economics 65, 1-20. 


\section{Appendix}

\section{Appendix: Data details}

\section{A. Occupations}

Table A1 reports the definition of the occupation breakdown.

Table A1 - Occupations

\begin{tabular}{ll}
\hline \hline Occupation & Definition \\
\hline Management & CS $=2$ or $C S=3$ or $C S=73$ (for some years) \\
Professionals & CS $=4$ or $C S=74$ \\
White Collar & $C S=52$ or $C S=53$ or $C S=54$ or $C S=55$ or $C S=56$ \\
Qualified Blue Collar & $C S=62$ or $C S=63$ or $C S=64$ or $C S=65$ \\
Non-qualified Blue Collar & $C S=67$ or $C S=68$ or $C S=69$ \\
\hline \hline
\end{tabular}

